\title{
Developing Mathematics Learning Materials based on Multiple Intelligence Theory, Learning Trajectory, and Conceptual Knowledge in the Topic of Probability for Eighth Graders
}

\author{
Endah Kusrinia), Ilham Rizkianto $^{\text {b) }}$ \\ Department of Mathematics Education, Faculty of Mathematics and Natural Science \\ Yogyakarta State University \\ Yogyakarta, Indonesia \\ a)endahkusrini96@gmail.com, ${ }^{\text {b) }}$ ilham_rizkianto@uny.ac.id
}

\begin{abstract}
This research aims to develop mathematics learning materials based on multiple intelligence theory and learning trajectory with conceptual knowledge oriented in the topic of probability for Junior High School's students grade VIII, which are valid, practical, and effective. The learning materials includes Lesson Plan and Worksheet that provide various facilities to students, for example through variations of learning activities, contexts, and illustrations, and by emphasizing on the hypothesis of students' thinking and teachers' alternatives responses so that the teachers can handling the difficulties which students face during the learning process. Type of the research was research and development with ADDIE model, consisting of Analysis, Design, Development, Implementation, and Evaluation. The lessons plan was valid with a score of 3.99 on a scale 5. While the worksheet obtained a score 4.09 on a scale 5 with valid category. Based on practicality evaluation result of student's questionnaire, learning materials obtained a score 3.47 on a scale 5 with practical category and observation sheet of learning implementation percentage was $\mathbf{8 6 . 8 4 \%}$. Then, there are $86.11 \%$ students who have a minimum understanding of the concept in the high category. Based on z-test, the learning materials are effective with level of significant 0.05 .
\end{abstract}

Keywords-learning materials; multiple intelligence theory; learning trajectory; conceptual knowledge; probability

\section{INTRODUCTION}

A concept is defined as knowledge structure of common characteristics of different substances and events captured by human brain [1]. Moreover, conceptual knowledge is rich with relation, and refers to the basic mathematics and relations between the ideas that illustrate mathematical procedures, and give it a meaning [2]. Therefore, students who have good conceptual knowledge are not only able to solve problems in certain ways or procedures, but can understand their properties, and be able to use the concept to solve problems related to other concepts. In Curriculum 2013, developed competencies are sourced from Main Competencies or Kompetensi Inti $(K I)$. Third Main Competence for $8^{\text {th }}$ grade students is to understand and apply the knowledge (factual, conceptual, and procedural) based on his curiosity about science, technology, art, and culture related phenomenon and visible eye events [3]. Therefore, conceptual knowledge is very important for students.

However, conceptual knowledge of Indonesian students has not been satisfactory. It can be seen from the results of Trends in International Mathematics and Science Study (TIMSS). TIMSS is an international study to assess mathematics learning outcomes that include mastery of content, concepts, and procedures for elementary and junior high school's students. TIMSS measures learning outcomes in two domains: content and cognitive. The compositions of cognitive domain are knowing, applying, and reasoning. While the compositions of content domain are number, algebra, geometry, data and change. For each domain, TIMSS sets a range of $0-1,000$ with an International average of 500 [4].

Knowing refers to the student's knowledge base of mathematics facts, concepts, tools, and procedures. Applying focuses on the student's ability to apply knowledge and conceptual understanding in a problem situation. Reasoning goes beyond the solution of routine problems to encompass unfamiliar situations, complex contexts, and multi-step problems [4]. The achievements of Indonesia represented by $8^{\text {th }}$ grade students for cognitive domains in TIMSS 2007 and 2011 are still far below the maximum score, even still far away from the International averages. Cognitive domain's achievements of Indonesia in 2007 and 2011 can be seen in Table 1. Based on Table 1, knowing, applying, and reasoning's ability of Indonesian students on mathematical concepts are still lacking.

TABLE 1. INDONESIAN COGNITIVE DOMAIN'S ACHIEVEMENTS

\begin{tabular}{|c|c|c|c|}
\hline \multirow{2}{*}{ Year } & \multicolumn{3}{|c|}{ Cognitive Domain } \\
\cline { 2 - 4 } & Knowing & Applying & Reasoning \\
\hline 2007 & 391 & 396 & 394 \\
\hline 2011 & 378 & 384 & 388 \\
\hline
\end{tabular}


Meanwhile, the score of Indonesia in content domain of TIMSS 2011 is 386, and the score in TIMSS 2007 is 397 [4]. These results also brought Indonesia below the international average score of 500 and made Indonesia into the low level category. The achievements in each topic of the content domain is shown in Table 2. It can be seen that the mastery concept of students on each topic is very low. Based on these data, topics data and chance becomes the lowest.

TABLE 2. THE ACHIEVEMENTS IN THE CONTENT DOMAIN

\begin{tabular}{|c|c|c|c|c|}
\hline \multirow{2}{*}{ Year } & \multicolumn{4}{|c|}{ Content Domain } \\
\cline { 2 - 5 } & Number & Algebra & Geometry & $\begin{array}{c}\text { Data and } \\
\text { Change }\end{array}$ \\
\hline 2007 & 393 & 399 & 387 & 382 \\
\hline 2011 & 375 & 392 & 377 & 376 \\
\hline
\end{tabular}

Indonesia is also participating in the Program for International Student Assessment (PISA). PISA is an international study to assess the learning outcomes of 15 -yearold students. The assessment does not determine whether students can reproduce knowledge, it also examines how well students can extrapolate from what they have learned and can apply that knowledge in unfamiliar settings, both in and outside of school [5].

To solve real problems in PISA, students needs a mathematical processes that are involving the understanding of mathematical concepts [6]. In addition, being able to apply the concept to solve problem is one of the indicator that students are understand the concept well [7]. Unfortunately, the achievement of Indonesia in PISA was still not satisfactory. In PISA 2015, the acquisition of Indonesian students' mathematics score is 403, below the international average score of 493 [5]. While the result in PISA 2012 shows the acquisition of Indonesian mathematics score is 375 , below the international average score of 494 [8]. Based on these results, the conceptual knowledge of Indonesian students are still lacking.

In addition to the international studies' data, the lack of conceptual knowledge can be seen from the data of junior high school's national examination 2016. National examination aimed to assess or evaluate the result of education process in Indonesia. Based on the data of national examination's result in 2016, the average score of Indonesian students' mathematics nationally is 50.24 from the maximum score of 100 [9]. Percentage of mastery for each topic can be seen in Table 3[9].

TABLE 3. PERCENTAGE OF MASTERY FOR EACH TOPIC

\begin{tabular}{|l|c|}
\hline \multicolumn{1}{|c|}{ Topic } & Mastery (\%) \\
\hline Number & 52.74 \\
\hline Algebra & 52.97 \\
\hline Geometry and Measurement & 47.19 \\
\hline Statistics and Probability & 46.73 \\
\hline
\end{tabular}

Based on Table 3, statistics and probability are the lowest as the same result at state junior high school (SMP N) 1 Prambanan. SMP N 1 Prambanan is one of the state school with B category based on the result of national examination in 2016. Percentage of mastery for each topic based on the result of national examination in SMP N 1 Prambanan 2016 are shown in Fig. 1. Based on Fig. 1, statistics and probability are the lowest with percentage $67.88 \%$. Therefore statistics and probability include materials that are difficult for students and understanding of the concepts related to statistics and probability still needs to be improved.

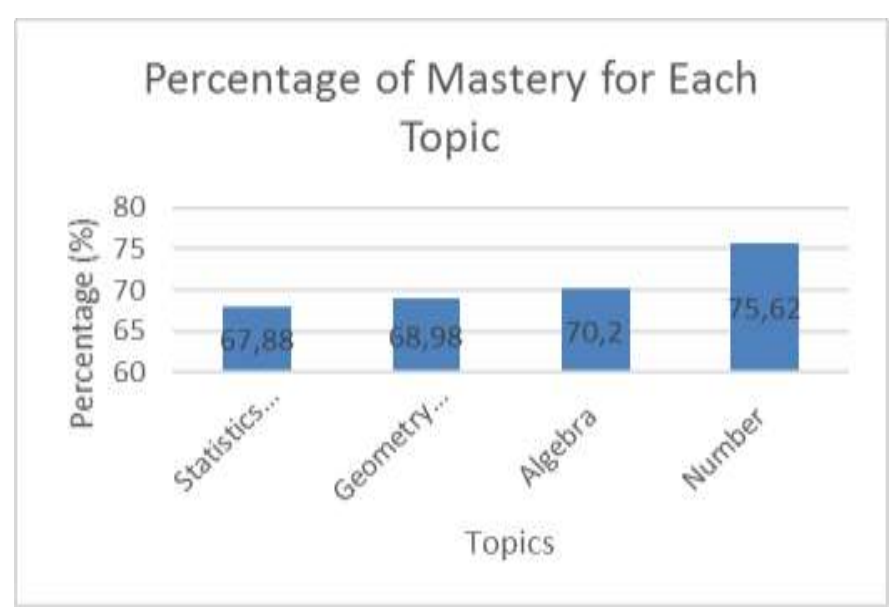

Fig. 1. Percentage of mastery for each topic in SMP N 1 Prambanan

The concept of probability is indeed difficult to understand scientifically as a theoretical interpretation of the real phenomena, one has to deal with typical misconceptions and beliefs, and knowledge about future events that is often based on divinatory predictions that have arisen from a magical ancestral way of thinking [10]. Nevertheless, the concept of probability remain important to teach. Reference [10] gives two reasons why student needs to learn about probability. The first reason is learning probability is a foundation for learning more advanced subjects, such as statistics or other science topics. The second reason is learning probability is essential to help prepare students for life, since random events and chance phenomena permeate our lives and environments.

In Indonesia, the concept of probability began to be taught in junior high school and will be continued in senior high school's level. The key in teaching probability is customized to the level of students, and how the concept can help prepare students' lives. Younger children can build an intuitive model that can help them to build the correct knowledge. But wrong intuitions that are acquired early are difficult to change and can later causes difficulties in learning [10]. Therefore, building a correct conceptual understanding of probability is very important, especially for junior high school's students, because the concept consist of new concepts and will be the base for them to learn more at senior high school's level.

Teachers as a facilitator have a role to assist students in building knowledge and understanding the concepts in every lesson. Every educational unit is required to undertake the planning, implementation, and assessment of the learning process to improve the efficiency and effectiveness of the graduate competence's achievement [11]. Teachers as a part of educator should pay attention to these aspects, especially 
related to planning phase. One form of planning in the learning process is preparing the learning materials.

When preparing learning materials, teachers should pay attention to students' hypothetical learning trajectory. Hypothetical Learning Trajectory (HLT) is made up of three components: the learning goal that defines the direction, the learning activities, and the hypothetical learning process as a prediction of how the students' thinking and understanding [12]. Teacher should notice that it is possible for every student in the class to have different way of thinking and understanding. By knowing the way of students' thinking and understanding, teachers can prepare about responses to each students' actions, including to prepare strategies for handling students' difficulties [13]. In addition, HLT could provide a framework for conceptualizing the creation of sets of lessons aimed at developing a new concept [14]. Therefore it is important for teacher to refer HLT when they are developing learning materials.

In the learning process, teacher should pay attention about the diversity of students' intelligence tendencies too. Intelligence is the ability to solve problems, or to create products, that are valued within one or more cultural settings [15]. It means that ways to solve problems between one person and another person is possible to be different. It indicates that each individual has a tendency of different types of intelligence. Furthermore, all human beings possess not just a single intelligence [15].

Learning will be more effective if it is customized to the characteristics of students. There are students who easily understand a concept by practicing, drawing, reading written reference sources, or by other activities. By knowing the tendency of each student's intelligences, does not mean that teachers have to design different learning process at one time, but it would be better if the teacher is able to present the learning process with variation in order to facilitate the students with different intelligence's tendency in the classroom.

Lesson plan and worksheet based on Multiple Intelligences Theory are effective with mathematical connection's ability oriented [16]. The mathematical connection's ability or able to link various concepts both in and outside of mathematics is an indicator of achieving conceptual understanding [17]. When students can connect mathematical ideas, their understanding is deeper and more lasting [18].

Students who learn mathematics based on Multiple Intelligences are better than students who learn mathematics with common method in term of conceptual knowledge [19]. Mathematics learning materials refer to Realistic Mathematics Education (RME) approach based on Multiple Intelligences also proved effective in terms of student achievement [20]. Learning based Multiple Intelligence Theory (MIT) can improve the achievement of students who have difficulty in learning mathematics [21]. Reference [21] added that learning with MIT makes it easier for students to understand the concepts and reduce some mistakes in addition, subtraction, and multiplication. Hence, pay attention to the tendency of students' intelligences can help students to understand a mathematical concept better.

Based on the description above, it is necessary to conduct a research which is aimed to develop learning materials based on multiple intelligence theory and learning trajectory with conceptual knowledge oriented in the topic of probability for eight graders. This research is also describing the quality of the developed learning materials based on validity, practicality, and effectiveness. The learning materials includes lesson plan and worksheet.

\section{RESEARCH METHOD}

Type of this research is research and development (R\&D), to develop learning materials based on multiple intelligence theory and learning trajectory with conceptual knowledge oriented in the topic of probability for eight graders. The learning materials includes Lesson Plan and Worksheet. The development model of this research is ADDIE development model developed by Dick and Carey, which consist of five steps: Analysis, Design, Development, Implementation, and Evaluations.

Analysis aimed to analyze the problems that may be encountered during mathematical learning process in junior high school, especially related to the lacking of students' conceptual knowledge, so that it is necessary to develop learning materials based on multiple intelligence theory and learning trajectory with conceptual knowledge oriented in the topic of probability. There were four types of analysis that included needs analysis, analysis the characteristics of students, curricula analysis, and analysis of the situation.

Design aimed to design the prototype of the product. Design consist of designing lesson plan and student worksheet based on multiple intelligence theory and learning trajectory, and also designing the research instruments to assess the quality of product. Development aimed to produce the product based on the design before. Then, the developed product will be validated by expert lecturers and mathematics teacher to know the validity of developed product. Then, continued the revision phase of the product based on the suggestions and comments from validator.

Implementation aimed to know the practicality and effectiveness of learning materials. The effectiveness of the learning materials is measured by test in the end of learning process. Then, student completed the questionnaire to know the practicality of developed product, besides the observation sheet of learning implementation that completed by observer in every lessons. Evaluation aimed to analysis practicality and effectiveness of the developed learning materials after implementation. Then, continued to revise the developed learning materials based on the suggestion and comments obtained during implementation.

This research conducted from April until May 2017 in SMP N 1 Prambanan, Klaten, Jawa Tengah, Indonesia. Type of data in this study were qualitative and quantitative. Qualitative data obtained from suggestions and comments from validators, teacher, students, and observer. This data used to revise the developed product. Quantitative data obtained from the score of learning materials' validation 
assessment sheet, score of students' questionnaire, score of learning implementation's observation sheet, and score of student achievement test.

The data of this research consist of validity, practicality, and effectiveness' data. Data of validity derived from the average of validation assessment sheets scores from expert lecturers and mathematics teacher as validator. Data of practicality derived from the average score of student responses from $8^{\text {th }}$ grade students class E SMP $N$ Prambanan, and data from the average score of learning implementation's observation sheet from observer. Data of effectiveness derived from the average score of student achievement test. Besides, there are data from suggestions and comments from questionnaire or implementations notes, and data from student tendency intelligence's questionnaire.

Instrument used to measure the validity are lessons plan validation sheet and worksheet validation sheet. Validity of lesson plan is assessed by eight aspects: (1) completeness of lesson plan's identity, (2) appropriateness of indicators and learning objectives, (3) content validity or learning materials, (4) appropriateness of learning methods, (5) appropriateness of learning activities, (6) appropriateness of learning media or resources, (7) appropriateness of instrument evaluation, and (8) linguistics aspect [22]. Validity of worksheet is assessed by four aspects: (1) content validity, (2) appropriateness to didactic requisite, (3) appropriateness to construct requisite, and (4) appropriateness to technic requisite [23].

The product called practical if the product usable and easily to use [24]. Then, researchers can observe the learning implementation to assert that the product is easily to use [25]. So instruments of practicality are student response questionnaire and observation sheet of learning implementation. Effectiveness is assessed by students' achievement [24] [25]. Instrument of effectiveness is students' achievement test. And the developed product said to be effective if more than $70 \%$ of students have a minimum understanding of the concept in the high category.

The learning materials validation sheet and student response questionnaire are analyzed by several steps, such as data tabulation, calculate the average score, convert the average score into qualitative criteria based on Table 4 [26], and make conclusion. The developed learning materials called valid and practical if it can achieve good category.

TABLE 4. DATA CONVERSION CRITERIA

\begin{tabular}{|c|c|}
\hline Interval Score & Category \\
\hline $\bar{x}>\bar{x}_{2}+1,8 S b_{i}$ & Very Good \\
\hline $\bar{x}_{2}+0,6 S b_{i}<\bar{x} \leq \bar{x}_{2}+1,8 S b_{i}$ & Good \\
\hline $\bar{x}_{4}-0,56<\bar{x}_{2} \leq \bar{x}_{4}+0,6 S b_{i}$ & Enough \\
\hline $\bar{x}_{2}-1,8 S b_{i}<\bar{x} \leq \bar{x}_{2}-0,6 S b_{i}$ & Less Good \\
\hline $\bar{x} \leq \bar{x}_{2}-1,8 S b_{i}$ & Very Less \\
\hline
\end{tabular}

with,

$\overline{x_{\mathrm{I}}}=$ ideal mean score $=\frac{1}{2}($ ideal maximum score + ideal minimum score)
$S b_{i}=$ ideal standard deviation $=\frac{1}{6}($ ideal maximum score - ideal minimum score)

$\bar{x}=$ average score obtained

Observation sheet of learning implementation is analyzed by several steps, such as calculate the score, calculate the percentage of learning implementation, convert the percentage into qualitative criteria based on Table 5 [27], and make conclusion. The developed learning materials called practical if it can achieve good category.

TABLE 5. DATA CONVERSION CRITERIA

\begin{tabular}{|c|l|}
\hline Interval Percentage (\%) & \multicolumn{1}{c|}{ Category } \\
\hline $85<p$ & Very Good \\
\hline $70<p \leq 85$ & Good \\
\hline $50<p \leq 70$ & Less Good \\
\hline$p \leq 50$ & Bad \\
\hline
\end{tabular}

with $p$ is percentage of learning implementation.

The effectiveness of learning materials is analyzed by the result of conceptual knowledge test. The product said to be effective if more than $70 \%$ of students have minimum understanding of the concept in the high category. It is done through the following steps: (1) calculate the test result of each students, (2) determine the conceptual knowledge category of each students based on Table 6 [28], (3) calculate the proportion of students who have minimum understanding of the concept in high category, (4) examine the normality, and (5) examine the hypothesis.

TABLE 6. CONCEPTUAL KNOWLEDGE CATEGORY OF STUDENT

\begin{tabular}{|c|l|}
\hline Interval Score & \multicolumn{1}{|c|}{ Category } \\
\hline $80<N \leq 100$ & Very High \\
\hline $60<N \leq 80$ & High \\
\hline $40<N \leq 60$ & Enough \\
\hline $20<N \leq 40$ & Low \\
\hline $0<N \leq 20$ & Very Low \\
\hline
\end{tabular}

with $N$ is the score of student achievement test.

\section{RESUlt AND DISSCUSSION}

Developing learning materials of this research using ADDIE model, consist of five stages: analysis, design, development, implementation, and evaluation.

First, analysis consist of needs analysis, analysis the characteristics of students, curricula analysis, and analysis of the situation. The result of need analysis identified that: (1) junior high school's students in Indonesia have low conceptual knowledge based on the result of TIMSS in 2007 and 2011, and the result of PISA in 2012 and 2015, (2) based on the result of TIMSS in 2007 and 2011, junior high school's students in Indonesia have low achievement on mastery concept in all topic, such as: number, algebra, geometry, data and change. Among these topics, topic data and change are the lowest, (3) based on the result of national examination (UN) in 2016, topic statistics and probability occupy the lowest mastery, (4) based on the result of UN SMP N 1 Prambanan in 2016, topic statistics and probability also occupy the lowest 
mastery, (5) based on observation in SMP N 1 Prambanan, mathematics learning materials did not used as optimum, (6) learning process was teacher centered where teacher used expository method, (7) teacher focus on single learning trajectory, (8) learning process do not facilitate the students with different intelligence's tendency in the classroom.

The result of curricula analysis consist of identified the main competence and basic competence or Kompetensi Dasar (KD) of probability referring to the Curriculum 2013. Students characteristics' analysis identified that: (1) student did not construct their own knowledge because the teacher transfer all of mathematical concept directly to student by expository method, and (2) just a few students who ask to the teacher about the materials that they did not understand yet. Situation analysis identified that the research suitable to undertaken at SMP N 1 Prambanan.

Second, researchers designs the prototype of the product. Design consist of designing lesson plans and student worksheet based on multiple intelligence theory and learning trajectory, and also designing the research instruments to assess the quality of product. It is resulted the draft of lesson plan with identity column, formulation of main competence (KI) and basic competence (KD), indicators, learning objectives, learning approach that will be used, design of learning activity in every lessons, design of instrument evaluation, time allocation, learning media and resources.

While the draft of worksheet consist of three parts: introduction, content, and closing. There are two kind of worksheet: worksheet for students and worksheet for teachers. Worksheet for teachers is the same with worksheet for students, but worksheet for teachers followed by key answer. The learning activity developed using scientific approach refer to multiple intelligence theory and learning trajectory, so in this stage, researchers also determine the type of intelligences that will be facilitated in every lessons. Besides, lesson plan and teacher's worksheet also followed by hypothesis of students thinking and teacher's alternatives responses for every possibility so that teacher can handling the difficulties which students face during the learning process.

Stage of design also resulted the draft of instrument to assess the quality of learning materials developed, such as validation sheet, students' response questionnaire, instrument test, and observation sheet of learning implementation with its components.

Third, development stage consist of developing or producing the product based on the design before. It was resulted the lessons plan in the topic of probability for six meetings. While, there are two kind of worksheet: worksheet for students and worksheet for teachers. Worksheet for students consist of thirteen components, such as: cover, title page, preface, table of content, the history of probability, introduction, preliminary, learning activity, conclusion column, competency test or exercise, project task, bibliography, and about author.

Worksheet for teachers has same component with worksheet for students, but worksheet for teacher followed by key answer, direction for teacher, information about type of intelligences' tendency that facilitated, hypothesis of students' answer, and teacher's alternatives responses.

Then, the developed product was validated by expert lecturers and mathematics teacher to know the validity of developed product. The result of validation shows that learning materials and instruments developed proper to be implemented with revision. Then, continued the revision phase of the product based on the suggestions and comments from validator. Data of lesson plan's validity was gotten from the average of eight aspects. The validity result of lesson plan is shown in Table 7 . Based on the result, lesson plan was valid and it could be implemented in learning.

TABLE 7. VALIDITY RESULT OF LESSON PLAN

\begin{tabular}{|c|l|c|c|c|}
\hline No. & Aspects of Assessment & $\begin{array}{c}\text { Maximum } \\
\text { Score }\end{array}$ & $\begin{array}{c}\text { Average } \\
\text { Score }\end{array}$ & Category \\
\hline 1 & Identity & 5 & 4.33 & $\begin{array}{c}\text { Very } \\
\text { Good }\end{array}$ \\
\hline 2 & $\begin{array}{l}\text { Indicators and Learning } \\
\text { Objectives }\end{array}$ & 5 & 3.89 & Good \\
\hline 3 & Material & 5 & 4 & Good \\
\hline 4 & Learning Method & 5 & 4 & Good \\
\hline 5 & Learning Activity & 5 & 3.93 & Good \\
\hline 6 & $\begin{array}{l}\text { Learning Media and } \\
\text { Resources }\end{array}$ & 5 & 4 & Good \\
\hline 7 & Assessment or Evaluation & 5 & 4 & Good \\
\hline 8 & Linguistic & 5 & 3.83 & Good \\
\hline & \multicolumn{4}{|c|}{ Average } \\
\hline
\end{tabular}

Meanwhile data of worksheet's validity was gotten from the average of four aspects. The validity result of worksheet is shown in Table 8. Based on the result, worksheet was valid and it could be implemented in learning.

TABLE 8. VALIDITY RESULT OF WORKSHEET

\begin{tabular}{|c|c|c|c|c|}
\hline No. & $\begin{array}{c}\text { Aspects of } \\
\text { Assessment }\end{array}$ & $\begin{array}{c}\text { Maximum } \\
\text { Score }\end{array}$ & $\begin{array}{c}\text { Average } \\
\text { Score }\end{array}$ & Category \\
\hline 1 & $\begin{array}{l}\text { Material/ Content } \\
\text { Requirements }\end{array}$ & 5 & 4.11 & Good \\
\hline 2 & $\begin{array}{l}\text { Didactical } \\
\text { Requirements }\end{array}$ & 5 & 4 & Good \\
\hline 3 & $\begin{array}{l}\text { Construction } \\
\text { Requirements }\end{array}$ & 5 & 4.15 & Good \\
\hline 4 & $\begin{array}{l}\text { Technical } \\
\text { Requirements }\end{array}$ & 5 & 4.12 & Good \\
\hline & \multicolumn{2}{|c|}{ Average } & 4.09 & Good \\
\hline
\end{tabular}

Fourth, learning materials that have been validated and revised according to the suggestions and comments from the validator are implemented in the class VIII E SMP N 1 Prambanan. This class consist of 36 students. Lesson plan and worksheet based on Multiple Intelligence theory and Learning Trajectory are arranged for six meetings. In the first meeting, implementation of learning materials begin with introduction. Then students asked to complete tendency intelligences' questionnaire to determine the tendency of intelligences of each student. Identification of students' intelligences tendency was used to determine groups.

In general, the learning process undertaken includes preliminary activity, main activity, and closing activity according to lesson plan. In the preliminary activity, the 
teacher initiates the learning activities by greeting, praying together, and checking the attendance of the students. Then teacher informs the learning objectives and the scope of the material to be studied. Teachers also provided apperception and gave motivation.

The main activity carried out with the steps of scientific methods based on multiple intelligences theory in order to facilitate the tendency of students' intelligence. Main activity include observing, questioning, collecting information, associating, and communicating. Observing activities was done by observing the context of the problems within the worksheet. Then at the questioning stage, students asked to make a question based on what they have observed. After that, students were asked to collecting information in order to find the answers of the questions they ask. Collecting information's activities was realized through group discussion or try to play some games.

In the associating stage, students were asked to answer questions in worksheet. These questions aimed to facilitate students in order to process or associate information so that students are able to deduce the conclusion of the learning activities they have done. In other word, students could build knowledge themselves. Then, students were asked to communicate the results of the discussions they have done. Communicating activities was done through presentations. In closing activity, teacher guided students to make a conclusion, make reflection, doing some individual tasks to check students' understanding, giving information about the next meeting, praying together, and greeting. The example of problems or activities used in the worksheet are shown in Table 9.

The fifth stage was evaluation. Evaluation was done by revising the developed learning materials based on suggestions and comments obtained from questionnaire and implementations notes, such as: there was some typo, and revised the hypothesis of students' responses and teacher's alternatives responses. Besides, researchers also analyzed the quality of learning materials in the aspect of practicality and effectiveness.

Data of practicality was gotten from the average score of students' responses and the average percentage of learning implementations' observation in every meeting. Students' responses questionnaire consist of two aspects: usefulness and easiness. The practicality result based on students' responses is shown in Table 10. Based on the result, learning materials was practical with score of 3.47 on a scale 5 . While, the result of learning implementation's observation sheet percentage was $86.84 \%$. From these results, learning materials based on multiple intelligence theory and learning trajectory was practical.
TABLE 9. STUDENTS' ACTIVITY IN WORKSHEET

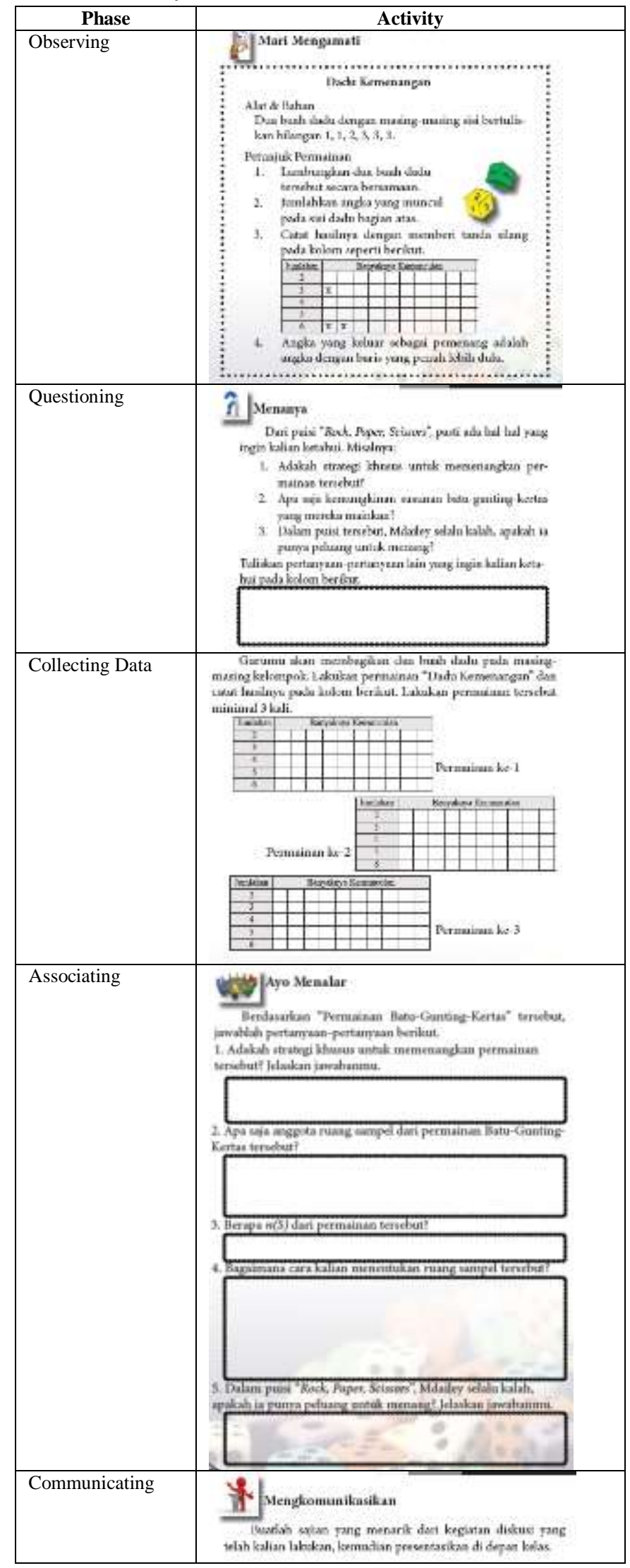


TABLE 10. PRACTICALITY RESULT

\begin{tabular}{|c|c|c|c|}
\hline $\begin{array}{c}\text { Aspects of } \\
\text { Assessment }\end{array}$ & $\begin{array}{c}\text { Maximum } \\
\text { Score }\end{array}$ & $\begin{array}{c}\text { Average } \\
\text { Score }\end{array}$ & Category \\
\hline Usefulness & 5 & 3.58 & Good \\
\hline Easiness & 5 & 3.41 & Good \\
\hline \multicolumn{2}{|c|}{ Average } & 3.47 & Good \\
\hline
\end{tabular}

The effectiveness of learning materials was assessed through students test result. The developed product said to be effective if more than $70 \%$ of students have a minimum understanding of the concept in the high category. The result of the test were analyzed through: test of normality and hypothesis testing.

Test of normality aimed to determine whether the data derived comes from a normal distributed population or not. The hypothesis used are follow:

$H_{0}$ : data derived from a population that are normally distributed.

$H_{1}$ : data derived from a population that are not normally distributed.

Normality test using SPSS statistics with One-Sample Kolmogorov-Smirnov Test. $H_{0}$ acceptable if the significance value is greater than 0.05 . The result of normality test is shown in Fig. 2. Based on Fig. 2, the level of significance is greater than 0.05 so the data derived from a population that are normally distributed.

Tests of Normality

\begin{tabular}{|r|r|r|r|r|r|r|}
\hline & \multicolumn{3}{|c|}{ Kolmogorov-Smirnov $^{\mathrm{a}}$} & \multicolumn{3}{c|}{ Shapiro-Wilk } \\
\cline { 2 - 7 } & Statistic & $\mathrm{df}$ & \multicolumn{1}{c|}{ Sig. } & Statistic & \multicolumn{1}{c|}{ Df } & \multicolumn{1}{c|}{ Sig. } \\
\hline data & .112 & 36 & $.200^{*}$ & .973 & 36 & .502 \\
\hline
\end{tabular}

a. Lilliefors Significance Correction

Fig. 2. Normality test with One-Sample Kolmogorov-Smirnov Test

Hypothesis testing aimed to determine whether the percentage of students who have a minimum understanding of the concept in the high category are more than $70 \%$ or not. In general, the result of the test is shown in Table 11. Based on the result there was $86.11 \%$ students who have a minimum understanding of the concept in the high category. Based on ztest, the learning materials was effective with level of significant 0.05 .

TABLE 11. THE RESULT OF THE TEST

\begin{tabular}{|c|l|c|}
\hline Interval Score & \multicolumn{1}{|c|}{ Category } & The Number of Students \\
\hline $80<N \leq 100$ & Very High & 6 \\
\hline $60<N \leq 80$ & High & 25 \\
\hline $40<N \leq 60$ & Enough & 5 \\
\hline $20<N \leq 40$ & Low & 0 \\
\hline $0<N \leq 20$ & Very Low & 0 \\
\hline
\end{tabular}

\section{CONCLUSIONS}

Based on the result of research, the following conclusions can be drawn: (1) the development of learning materials based on multiple intelligence theory and learning trajectory with conceptual knowledge oriented in the topic of probability for eight graders using ADDIE model, consist of five stage: analysis, design, development, implementation, and evaluation, (2) the developed learning materials based on multiple intelligence theory and learning trajectory with conceptual knowledge oriented in the topic of probability for eight graders was required validity, practicality, and effectiveness criteria.

\section{RECOMMENDATION}

The learning materials was required validity, practicality, and effectiveness criteria, therefore it can be used for teacher to facilitate students in order to understand the concept of probability well. Nevertheless, it is necessary to revise the learning materials regularly after implemented. Because it is using hypothesis that is inherently uncertain nature of learning process, so teacher is regularly involved in modifying every aspect of the HLT [14].

\section{REFERENCES}

[1] T. Isleye and A. Isik, "Conceptual and Procedural Learning in Mathematics," Journal of the Korea Society of Mathematical Education Series D: Research in Mathematical Education, vol. 7, No. 2, 2003, pp. 91-99.

[2] K. H. Khashan, "Conceptual and Procedural Knowledge of Rational Numbers for Riyadh Elementary School Teachers," Journal of Education and Human Development, vol. 3, no. 4, 2014, pp. 181-197.

[3] Kemendikbud, "Permendikbud No. 24 Tahun 2016", Jakarta: Kemendikbud, 2016.

[4] I. V. S. Mullis, M. O. Martin, P. Foy, and Alka Arora, "TIMSS 2011 International Results in Mathematics," Boston: TIMSS \& PIRLS International Study Center, 2012.

[5] OECD, "PISA 2015 Results In Focus," 2016.

[6] A. Wijaya, Pendidikan Matematika Realistik Suatu Alternatif Pendekatan Pembelajaran Matematika, Yogyakarta: Graha Ilmu, 2012.

[7] S. Wardani, "Analisis SI dan SKL Mata Pelajaran Matematika SMP/MTs untuk Optimalisasi Tujuan Mata Pelajaran Matematika," Yogyakarta: Depdiknas, 2008.

[8] OECD, "PISA 2012 Results In Focus what 15-year-olds know and what they can do with what they know," 2014.

[9] Puspendik, Laporan Hasil Ujian Nasional Tahun Pelajaran 2015/2016, 2016.

[10] G. A. Jones, Exploring Probability in School, New York: Springer Science+Business Media, 2005.

[11] Kemendikbud, "Peraturan Menteri Pendidikan dan Kebudayaan Republik Indonesia Nomor 65 Tahun 2013 Standar Proses Pendidikan Dasar dan Menengah," Jakarta: Kemendikbud, 2013.

[12] M. A. Simon, "Reconstructing Mathematics Pedagogy from A Constructivist Perspective," Journal for Research in Mathematics Education, vol. 26, no. 2, 1995, pp. 114-145.

[13] A. Wijaya, "Hypothetical Learning Trajectory dan Peningkatan Pemahaman Konsep Pengukuran Panjang”, 2009.

[14] M. A. Simon and R. Tzur, "Explicating the Role of Mathematical Tasks in Conceptual Learning: An Elaboration of the Hypothetical Learning Trajectory," Mathematical Thinking and Learning, 6(2), 2004, pp. 91104.

[15] H. Gardner, Frames of Mind, New York: Basic Book, 2011.

[16] A. Kartikasari, "Pengembangan Perangkat Pembelajaran Matematika SMA Kelas $\mathrm{X}$ pada Materi Trigonometri dan Geometri dengan Pendekatan Problem-Based Learning Berbasis Multiple Intelligences Gardner Berorientasi pada Prestasi, Kemampuan Koneksi Matematis, dan Self-Esteem Siswa," PPs-UNY, 2016. (Thesis). 
[17] Kemendikbud, "Pedoman Mata Pelajaran (PMP) Matematika," Jakarta: Kemendikbud, 2014.

[18] NCTM, "Principles and Standards for School Mathematics," Reston, VA: Author, 2000.

[19] I. Rafianti, "Penerapan Model Pembelajaran Matematika Berbasis Multiple Intelligences untuk Meningkatkan Kemampuan Pemahaman Konsep, Penalaran Matematis, dan Self-Confidence Siswa MTs," UPI, 2013. (Thesis).

[20] R. Suryani, "Pengembangan Perangkat Pembelajaran Matematika dengan Pendekatan Realistic Mathematics Education (RME) Berbasis Teori Multiple Intelligences Howard Gardner, Berorientasi pada Prestasi dan Kemandirian Belajar Siswa Kelas VIII SMP,” FMIPA UNY, 2016. (Thesis)

[21] N. F. Al-Zyoud and Z. M. Nemrawi, "The Efficiency of Multiple Intelligence Theory (MIT) in Developing the Academic Achievement and Academic-Self of Students with Mathematical Learning Disabilities in the Areas of Addition, Subtraction, and Multiplication," American International Journal of Social Science, vol. 4 no. 2, 2015, pp. 171-180.
[22] A. Majid and C. Rochman, Pendekatan Ilmiah dalam Implementasi Kurikulum 2013, Bandung: Rosda, 2015.

[23] H. Darmodjo and J. R. E. Kaligis, Pendidikan IPA II, Jakarta: Depdikbud, 1992.

[24] N. Nieveen, "Prototyping to Reach Product Quality. Dalam Akker, J (Eds), Design Approaches and Tools in Education and Training," Springer Science+Business Media Dordrecht, 1999, pp. 125-135.

[25] Rohmat, "Desain Model Pengembangan Perangkat Pembelajaran Matematika," Jurnal Kreano, vol. 3 no.1. 2012, pp. 59-72.

[26] E. P. Widoyoko, Evaluasi Program Pembelajaran, Yogyakarta: Pustaka Pelajar, 2009.

[27] Y. Yamasari, "Pengembangan Media Pembelajaran Matematika Berbasis ICT yang Berkualitas," Prosiding, Seminar Nasional Pascasarjana X-ITS, Surabaya: Pascasarjana ITS, 2010.

[28] S. Arikunto, Manajemen Penelitian, Jakarta: Rineka Cipta, 1995. 